\title{
SPRAWOZDANIA ARCHEOLOGICZNE
}



INSTYTUT ARCHEOLOGII I ETNOLOGII POLSKIEJ AKADEMII NAUK

\section{SPRAWOZDANIA \\ ARCHEOLOGICZNE}

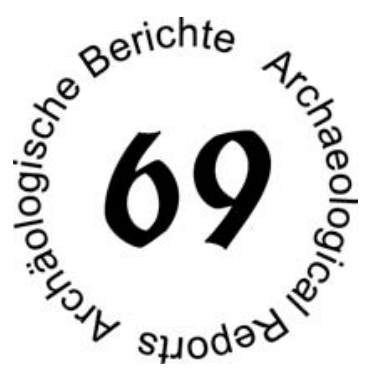

KRAKÓW 2017 
Copyright $(\bigodot$ by the Authors and Instytut Archeologii i Etnologii Polskiej Akademii Nauk 2017

Editor

StAWOMIR KADROW, slawekkadrow@gmail.com

Editorial Secretary

MAGDALENA DZIĘGIELEWSKA, madzinska@poczta.fm

Editorial Committee

SYLWESTER CZOPEK, JANUSZ KRUK (CHAIRMAN), JAN MACHNIK, SARUNAS MILISAUSKAS,

JOHANNES MÜLLER, JAROSLAV PEŠKA, ALEKSANDER SYTNIK, PRZEMYSŁAW URBAŃCZYK

All articles published in this volume of "Sprawozdania Archeologiczne" obtained approval of the following specialists: JUSTYNA BARON (Wrocław), WOJCIECHBLAJER (Kraków), TOMASZ BOCHNAK (Rzeszów), JANUSZ CZEBRESZUK (Poznań), LECHCZERNIAK (Gdańsk), KAROLDZIĘGIELEWSKI (Kraków), MAREK FLOREK (Lublin), MARTIN FURHOLT (Kiel, Germany), JACEK GACKOWSKI (Toruń), MAŁGORZATA GRUPA (Toruń), MACIEJ KACZMAREK (Poznań), MACIEJ KARCZEWSKI (Białystok), DAWID KOBIAŁKA (Poznań), ALEXANDRA KOZAK (Kyiv, Ukraine), ANJA HELLMUTH KRAMBERGER (Ljubljana, Slovenia), JERZY LIBERA (Lublin), PRZEMYSŁAW MAKAROWICZ (Poznań), JOLANTA MAŁECKA-KUKAWKA (Toruń), ANDRZEJ MICHAŁOWSKI (Poznań), OLIVER NAKOINZ (Kiel, Germany), DALIA POKUTTA (Stockholm, Sweden), MARCINS. PRZYBYŁA (Kraków), ANDRZE) ROZWAŁKA (Rzeszów), SEWERYN RZEPECKI (Łódź), HALINA TARAS (Lublin), TARAS TKACHUK (Galich, Ukraine), SENICA ȚURCANU (Jași, Romania), MARCIN WIEWIÓRA (Toruń), ANNA ZAKOŚCIELNA (Lublin)

English proofreading

AEDDANSHAW (excluding 1, 3, 5, 17)

Technical Editor and Layout

JOANNA KULCZYŃSKA-KRUK

(Centre for Mountains and Uplands Archaeology, Institute of Archaeology and Ethnology, Polish Academy of Sciences)

Cover: Cucuteni culture figurines from Brînzeni microregion. Photos by S.ȚERNA.

Courtesy of National Museum of History of Moldova

Editor's Address

CENTRE FOR MOUNTAINS AND UPLANDS ARCHAEOLOGY, INSTITUTE OF ARCHAEOLOGY

AND ETHNOLOGY, POLISH ACADEMY OF SCIENCES, 31-016 KRAKÓW, UL. StAWKOWSKA 17

PL ISSN 0081-3834

DOI: 10.23858/SA69.2017

Printed by PARTNER POLIGRAFIA Andrzej Kardasz

ul. Zwycięstwa 10, 15-703 Białystok

Edition: 300 pcs.

"Sprawozdania Archeologiczne" is regulary listed in the CEJSH, ERIH Plus 


\section{CONTENTS}

ARTICLES 9

\section{Geoff Carver, Matthias Lang}

No narrative so grand.

\section{Michał Pawleta}

Theatrum archaeologicum: staging the past via archaeological fêtes and historical re-enactment 33

Marie-Lorraine Pipes, Janusz Kruk, Sarunas Milisauskas

Variability in $4^{\text {th }}$ Millennium BC Livestock Management Practices in the Bronocice Region, Southeastern Poland

Thomas Saile, Martin Posselt, Bernhard Zirngibl

The earthworks at Altheim 71

\section{Jan Romaniszyn, Bogdan Petru Niculică, loan Ignat}

Funeral rites on the southern boundary of the Komarov culture

\section{Marcin Maciejewski}

The symbolism of hoard deposition places in the landscape of the late Bronze Age and the early Iron Age in the zone of the South Baltic Coastland and Lake Districts

\section{Marcin Burghardt}

Social stratification of the population of the forest-steppe area of the Dnieperland in the Early Scythian period

(VII - first half of $\mathrm{VI}$ cent. BC)

\section{Magdalena Natuniewicz-Sekuła}

The Craft of the Goldsmith in Wielbark Culture in the Light of the Finds from the Cemetery at Weklice, Elbląg Commune and Other Necropolis of Roman Period from Elbląg Heights. Technological Studies of Selected Aspects

Andriy B. Bardetskiy, Maciej Dębiec, Inna D. Potekhina and Thomas Saile

Raptus Sabinae? Of a female calvarium from the Bandkeramik settlement of Rovantsi in Volhynia 


\section{Dmytro Kiosak}

Kamyane-Zavallia, the Easternmost Linear Pottery Culture Settlement Ever Excavated

Maria Lityńska-Zając, Agnieszka Czekaj-Zastawny, Anna Rauba-Bukowska

Utilisation of cultivated and wild plants in the economy of the Linear Pottery Culture in the Upper Vistula basin

\section{Stanislav Țerna, Sergiu Heghea}

Middle and Late Copper Age settlements from the Brînzeni microzone on the Prut river: older research in a modern background

\section{Piotr Mączyński, Anna Zakościelna}

Flint inventories of Lublin-Volhynian culture burials from sites 1A and 2A in Strzyżów, Hrubieszów district, in light of the archaeological and traseological analysis

\section{Stanisław Wilk, Anita Szczepanek}

The first cremation traces in the Eneolithic period north of the Carpathian Mountains

\section{Magdalena Sudoł-Procyk, Kamil Adamczak, Grzegorz Osipowicz}

A flint dagger from Brzoza, Nowa Wieś Wielka com., Bydgoszcz dist., Kuyavian-Pomeranian Voivodeship

\section{Elżbieta Małgorzata Kłosińska, Sylwester Sadowski}

Long-distance connections of the south-eastern peripheries of the Lublin region at the time of the Lusatian culture in the light of archival and newly discovered materials

\section{Ewa Lisowska}

Bradatica from the Strzelińskie Hills

\section{Radosław Janiak}

About the burial-free kurgans once again

\section{Sławomir Kadrow}

(review) Florian Klimscha, Pietrele 1: Beile und Äxte aus Stein. Distinktion und Kommunikation während der Kupferzeit im östlichen Balkangebiet (= Archäologie in Eurasien 34). Bonn: Habelt-Verlag 2016, 382 pages, 87 plates 


\section{Aleksandra Sznajdrowska-Pondel}

(rev.) Tomasz J. Chmielewski and Edmund Mitrus (eds.), Pliszczyn, site no. 9. Eneolithic complex in the Lublin region (= Saved Archaeological Heritage 5). Pękowice - Wrocław 2015: Profil-Archeo Publishing House and Archaeological Studio, Archaeologia Silesiae Science Foundation, 248 pages, 71 figures, 34 tables and 21 plates in the text, published in Polish and English

\section{Elżbieta Sieradzka}

(review) A. Marciniak, I. Sobkowiak-Tabaka, M. Bartkowiak and M. Lisowski (eds), Kopydłowo, stanowisko 6. Osady neolityczne z pogranicza Kujawi Wielkopolski (= Ocalone Dziedzictwo Archeologiczne 6) (Kopydłowo, site 6. Neolithic settlements from the border-lands of Kuyavia and Greater Poland (= Saved Archaeological Heritage 6). Pękowice-Poznań 2015: Uniwersytet im. Adama Mickiewicza w Poznaniu, Profil-Archeo Publishing House and Archaeological Studio, 344 pages

\section{Beata Polit}

(review) Irina I. Gushchina and Denis V. Zhuravlev, Nekropol rimskogo vremeni Belbek IV v Yugo-Zapadnom Krymu (Part 1 - Text; Part 2 - Tables) (= Trudy Gosudarstvennogo Istoricheskogo muzeya 205). Moscow 2016: Istoricheskiy muzey, 272 pages, 18 charts, 75 unnumbered drawings, 317 tables, summary in German

\section{Tomasz Bochnak}

(review) A. V. Gudkova and E. Schultze, Gräberfeld und Siedlung Nagornoe 2. Ein Fundplatz der Sântana Mureş-Cernjachov-Kultur an der Unteren Donau (= Archäologie in Eurasien 35). Bonn 2017: Deutsches Archäologisches Institut, Eurasien-Abteilung, Verlag Dr Rudolf Habelt

\section{Elżbieta Sieradzka, Sergiy Taranenko}

Jan Gurba

Professor Andrzej Żaki (9th September 1923 - $4^{\text {th }}$ January 2017) 469

Anna Zakościelna, Jan Gurba

Professor Henryk Maruszczak - on the fifth anniversary of his death 
"Sprawozdania Archeologiczne" is regulary listed in the International Current Awareness Service: Anthropology. Selected material is indexed in the International Bibliography of social and Cultural Anthropology.

Indexed in:

IBZ- International Bibliography of Periodical Literature

IBZ-CD-ROM 